Note

\section{Isothiocyanates as an Attaching Repellent against the Blue Mussel Mytilus edulis}

\author{
Kazuo Ina, Reiko TaKasawa, Akihito Yagi, \\ Hideo ETOH and Kanzo SaKaTA* \\ Department of Agricultural Chemistry, \\ Shizuoka University, 836 Ohya, \\ Shizuoka 422, Japan \\ * Research Laboratory of Marine Biological Science, \\ Faculty of Agriculture, Shizuoka University, \\ Mochimune, Shizuoka 421-01, Japan
}

Received July 4, 1989
We have recently developed an improved bioassay method $^{\text {" }}$ for screening antifouling substances using the blue mussel, Mytilus edulis L., which causes serious fouling problems, especially in the cooling systems of power plants. We have already reported the isolation of antifouling substances: an acylated kaempferol glucoside ${ }^{2)}$ from Quercus dentata Thunberg, and an acylated rhaponticin ${ }^{3)}$ from Eucalyptus rubida. In the course of our further search

Table I. Repellent Activity of Ether Extracts OF WASABI $(W$. japonica) AND HORSE RADISH (C. armoracia) BY THE IMPROVED BIOASSAY METHOD ${ }^{1)}$

\begin{tabular}{lccc}
\hline & \multicolumn{4}{c}{ Sample amount $\left(\mathrm{mg} / \mathrm{cm}^{2}\right)$} \\
\cline { 2 - 4 } & 4.0 & 0.80 & 0.080 \\
\hline Wasabi & ++ & ++ & \pm \\
Horse radish & ++ & \pm & - \\
\hline
\end{tabular}

Table II. Repellent Activity of Isothiocyanates By the Improved BioAsSAy Method ${ }^{1)}$

\begin{tabular}{|c|c|c|c|c|c|c|c|c|}
\hline & \multicolumn{8}{|c|}{ Sample amount $\left[\mu \mathrm{mol} / \mathrm{cm}^{2}\right]$} \\
\hline & $\begin{array}{c}50 \\
(1)^{*}\end{array}$ & $\begin{array}{l}10 \\
(5)\end{array}$ & $\begin{array}{c}5 \\
(10)\end{array}$ & $\begin{array}{c}2.5 \\
(20)\end{array}$ & $\begin{array}{c}1 \\
(50)\end{array}$ & $\begin{array}{c}0.5 \\
(100)\end{array}$ & $\begin{array}{c}0.25 \\
(200)\end{array}$ & $\begin{array}{c}0.05 \\
(1000)\end{array}$ \\
\hline $\mathrm{CH}_{2}=\mathrm{CHCH}_{2} \mathrm{NCS}^{a, b}$ & $+t$ & $t$ & - & & & & & \\
\hline $\mathrm{CH}_{3} \mathrm{NCS}^{a}$ & + & - & & & & & & \\
\hline $\mathrm{CH}_{3} \mathrm{CH}_{2} \mathrm{NCS}$ & + & - & & & & & & \\
\hline $\mathrm{CH}_{3}\left(\mathrm{CH}_{2}\right)_{2} \mathrm{NCS}$ & + & - & & & & & & \\
\hline $\mathrm{CH}_{3}\left(\mathrm{CH}_{2}\right)_{3} \mathrm{NCS}^{a}$ & + & \pm & - & & & & & \\
\hline $\mathrm{CH}_{3}\left(\mathrm{CH}_{2}\right)_{4} \mathrm{NCS}$ & ++ & - & & & & & & \\
\hline $\mathrm{CH}_{3}\left(\mathrm{CH}_{2}\right)_{5} \mathrm{NCS}^{a}$ & ++ & + & \pm & - & & & & \\
\hline $\mathrm{CH}_{3}\left(\mathrm{CH}_{2}\right)_{6} \mathrm{NCS}^{* *}$ & ++ & + & - & & & & & \\
\hline $\mathrm{CH}_{3}\left(\mathrm{CH}_{2}\right)_{7} \mathrm{NCS}^{* *}$ & $t+$ & - & & & & & & \\
\hline $\mathrm{CH}_{3}\left(\mathrm{CH}_{2}\right)_{8} \mathrm{NCS}^{* *}$ & + & \pm & - & & & & & \\
\hline $\mathrm{CH}_{3}\left(\mathrm{CH}_{2}\right)_{9} \mathrm{NCS}^{* *}$ & + & \pm & - & & & & & \\
\hline $\mathrm{CH}_{3}\left(\mathrm{CH}_{2}\right)_{10} \mathrm{NCS}^{* *}$ & $+t$ & \pm & - & & & & & \\
\hline $\mathrm{CH}_{3}\left(\mathrm{CH}_{2}\right)_{12} \mathrm{NCS}^{* *}$ & + & - & & & & & & \\
\hline $\mathrm{CH}_{3}\left(\mathrm{CH}_{2}\right)_{13} \mathrm{NCS}^{* *}$ & ++ & \pm & - & & & & & \\
\hline $\mathrm{CH}_{3}\left(\mathrm{CH}_{2}\right)_{15} \mathrm{NCS}^{* *}$ & ++ & \pm & - & & & & & \\
\hline $\mathrm{CH}_{3} \mathrm{~S}\left(\mathrm{CH}_{2}\right)_{3} \mathrm{NCS}^{* *}$ & & & ++ & - & & & & \\
\hline $\mathrm{CH}_{3} \mathrm{~S}\left(\mathrm{CH}_{2}\right)_{6} \mathrm{NCS}^{* *, a}$ & & & ++ & - & & & & \\
\hline $\mathrm{CH}_{3} \mathrm{~S}\left(\mathrm{CH}_{2}\right)_{7} \mathrm{NCS}^{* *, a}$ & & & ++ & - & & & & \\
\hline $\mathrm{C}_{6} \mathrm{H}_{5} \mathrm{NCS}^{b}$ & ++ & + & + & - & & & & \\
\hline $\mathrm{C}_{6} \mathrm{H}_{5} \mathrm{CH}_{2} \mathrm{NCS}^{b}$ & & $+t$ & + & - & & & & \\
\hline $\mathrm{C}_{6} \mathrm{H}_{5}\left(\mathrm{CH}_{2}\right)_{2} \mathrm{NCS}^{a, b}$ & & & $+t$ & - & & & & \\
\hline $\mathrm{CH}_{3} \mathrm{~S}\left(\mathrm{CH}_{2}\right)_{6} \mathrm{NCS}^{* *, a}$ & & & & & & & & \\
\hline$+\mathrm{C}_{6} \mathrm{H}_{5}\left(\mathrm{CH}_{2}\right)_{2} \mathrm{NCS}^{a, b}(1: 1)$ & & & & $+t$ & - & & & \\
\hline $\mathrm{CuSO}_{4}$ & & & & & & $+t$ & + & - \\
\hline
\end{tabular}

* Units: $100 \times$ minimum dose of $\mathrm{CuSO}_{4}$ for ++ activity $\left(\mu \mathrm{mol} / \mathrm{cm}^{2}\right) /$ minimum dose of sample for ++ activity $\left(\mu \mathrm{mol} / \mathrm{cm}^{2}\right)^{1)}$

** Prepared by the method of Kjaer et al. ${ }^{71}$

a Isolated from wasabi. ${ }^{4,5\}}$

${ }^{b}$ Isolated from horse radish. ${ }^{5}$ 
to obtain repellents from other plant extracts, we found that ether extracts of the roots of wasabi, Wasabia japonica Matsum, and horse radish, Cochlelia armoracia L., showed repellent activity against the blue mussel $M$. edulis. Here, we report the repellent activity of isothiocyanates, the main pungent compounds, in wasabi and horse radish.

The wasabi and horse radish pastes, which were prepared by crushing frozen roots, were extracted with ether at room temperature. After removing the solvent, the repellent activity of the residue against the blue mussel $M$. edulis was tested using the improved bioassay method (Table I). ${ }^{1)}$ To date, many isothiocyanates have been isolated from wasabi and horse radish pastes. Allyl iso- thiocyanate is known to be the main pungent compound of wasabi and horse radish, and $\omega$-methylthioalkyl isothiocyanates $^{4 \prime}$ and $\beta$-phenyl ethyl isothiocyanates ${ }^{51}$ are present as minor pungent constituents. It has been also reported that isothiocyanates had antifouling activity against the marine fouling organisms. ${ }^{6)}$ Therefore, we expected that the repellent activity in wasabi and horse radish would be due to these isothiocyanates. The assay was carried out: on thick cardboard (Webron ${ }^{\circledR}$, Tokushu Seishi Co. Ltd.), sample zones ( $4 \mathrm{~cm}$ in diameter) being drawn and each zone coated with one sample of each extract or compound. After the solvent had evaporated, four test mussels were fixed around the circumference of

A
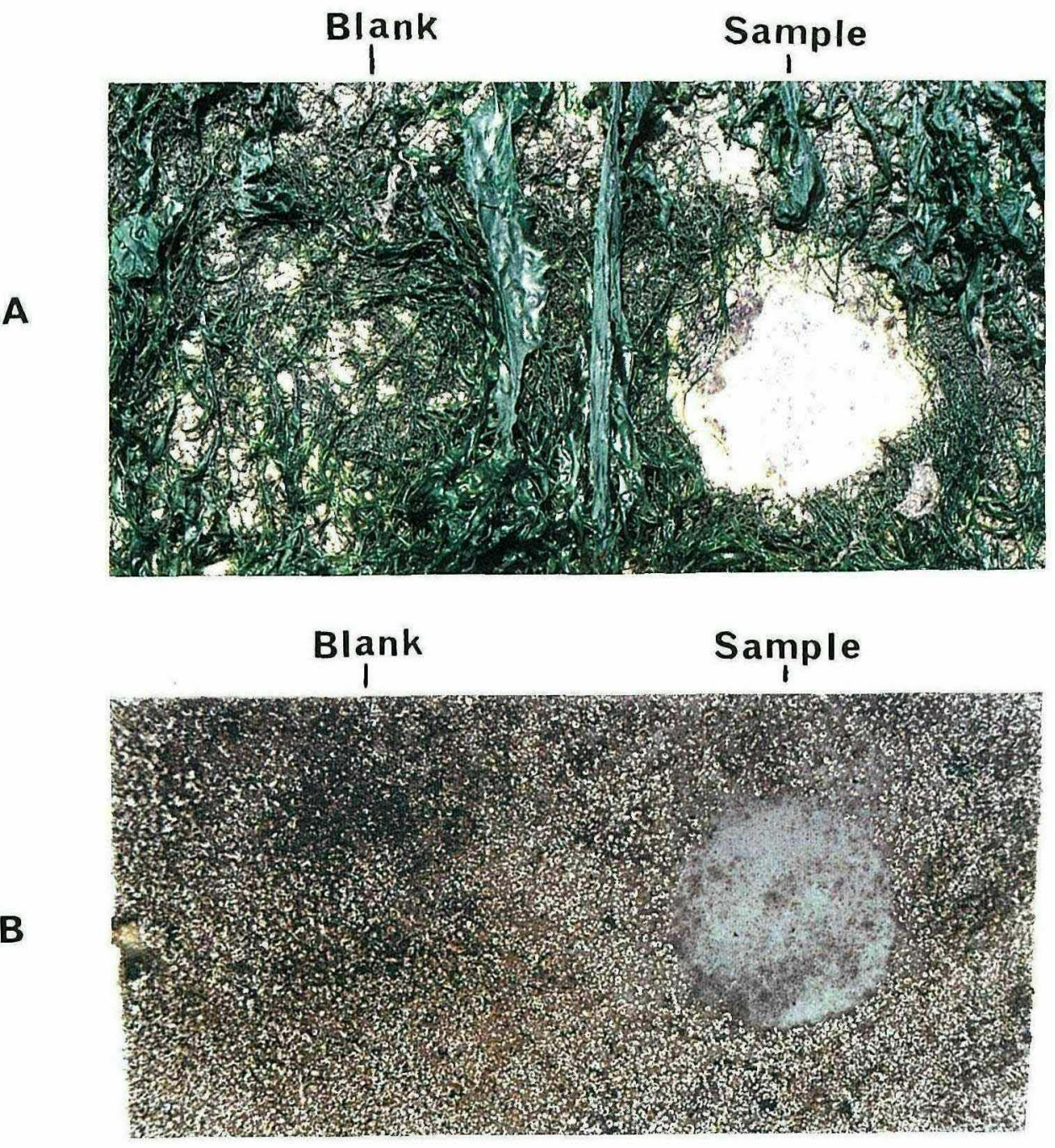

Fig. 1. Repellent Activity of 6-Methylthiohexyl Isothiocyanate in the Conventional Submerged Assay.

Dosage, $38 \mu \mathrm{mol} / \mathrm{cm}^{2}$; details in the text. A, after two months (from March 20 to May 20, 1988); B, after five months (from March 20 to August 18, 1988). Fouling organisms outside the sample zone were mainly sea weed in $\mathbf{A}$ and Dexiospira foraminosus (animal species) in $\mathbf{B}$, respectively. 
each zone. The assay plate was set at the bottom of an experimental aquarium with running sea-water, which was covered with a board to make it dark, and left for $3 \mathrm{~h}$. The mussels usually fix themselves on the plate by attaching many byssuses, and if the sample was active, the mussels attached their byssuses outside the zone. The activity was estimated by the ratio of byssuses attached outside the zones to the total number of byssuses. ${ }^{1)}$ Table II shows the repellent activities of isothiocyanates compared with that of cupric sulfate, one of the most popular antifouling substances, as a positive reference. All of the tested isothiocyanates showed repellent activity. It is noteworthy that $\omega$-methylthioalkyl isothiocyanates were much more active than the other alkyl and aryl isothiocyanates, and that $\beta$-phenyl ethyl isothiocyanate was slightly more active than benzyl isothiocyanate. This is the first time that the isothiocyanates have been found to have repellent activity against the attachment of the blue mussel.

One of the active isothiocyanates in the wasabi and horse radish, 6-methylthiohexyl isothiocyanate, was subjected to a conventional submerged assay in the Mochimune harbor of Shizuoka City. The sample mixed with polyvinyl butylal resin was fixed in a sample zone $(5 \mathrm{~cm}$ in diameter) on a polyvinyl chloride resin board. The amount of isothiocyanate was six- to ten-fold the minimum dose $(++)$. As shown in Fig. 1, apparent repellent activity was observed after treating the assay board for three or four months. That is, the repellent activity judged by the improved assay was also observed by the conventional submerged method, although only with one example. This improved assay method proved convenient for a first screening in the search for antifouling compounds.

\section{References}

1) K. Ina, R. Takasawa, A. Yagi, N. Yamashita, H. Etoh and K. Sakata, Agric. Biol. Chem., 53, 3319 (1989).

2) N. Yamashita, H. Etoh, K. Sakata, A. Yagi, H. Ina and K. Ina, Agric. Biol. Chem., 53, 1383 (1989).

3) N. Yamashita, H. Etoh, K. Sakata, H. Ina and K. Ina, Agric. Biol. Chem., 53, 2827 (1989).

4) K. Ina, H. Ina, M. Ueda, A. Yagi and I. Kishima, Agric. Biol. Chem., 53, 537 (1989).

5) M. Kojima, M. Uchida and Y. Akahori, Yakugaku Zasshi, 93, 453 (1973).

6) H. Fukui, Japan Kokai Tokkyo Koho, 74, 125, 524 (Dec. 2, 1974).

7) A. Kjaer, I. Larsen and R. Gmelin, Acta Chem. Scand., 9, 1311 (1955). 